ca. ett år etter avsluttet behandling viste betydelig tilbakegang av tuberkulomene (fig 4).

\section{Diskusjon}

Pasienten hadde disseminert spredning av $M$ tuberkulosis til en rekke av kroppens indre organer (lungene, urinveiene og sentralnervesystemet). Denne kombinasjonen er meget sjelden i Norge i dag. Årlig meldes urinveisaffeksjon hos $1 \%$, miliær spredning hos $1 \%$ og sentralnerveaffeksjon hos $0,5 \%$ av alle nye tilfeller med tuberkulose (5).

De aller fleste tuberkulosepasienter i Norge i dag er utenlandskfødte. Man antar at de fleste av disse er smittet $i$ opprinnelseslandet eller under reisen til Norge (6). Mange asylsøkere har trange og dårlige boforhold også etter ankomst til landet. Vår pasient bodde sammen med en rekke av sine landsmenn under meget vanskelige forhold. Siden han tidligere var BCG-vaksinert, var uten kjent tuberkulose og hadde negativt skjermbilde av lungene ved ankomst til Norge, er det mulig at han er blitt smittet her i landet. Denne mistanken ble styrket av informasjon om at en i bofellesskapet hadde startet behandling mot mistenkt lungetuberkulose før vår pasient ble syk.

Epididymitt er den vanligste manifestasjonen av urogenital tuberkulose (7). Den mest sannsynlige patogenesen er hematogen spredning til en nyre fra et primærfokus i en lunge. Etter reaktivering kan tuberkelbasiller spres via urinveiene til prostata og sædblærer, deretter retrograd til epididymis. Andre smitteveier til epididymis kan være direkte hematogen spredning dit, seksuell smitte eller smitte ved intravesikal BCGterapi ved overflatisk blærekreft. De fleste med urogenital tuberkulose har også nyreaffeksjon. Vår pasient hadde verken symptomer eller tegn til dette, men urindyr- kingen var positiv. Dette tyder på at han mest sannsynlig hadde et lite fokus også i nyrene.

Miliær tuberkulose har ubehandlet dårlig prognose. Det er vanligst hos immunsvekkede (3). Hos vår pasient fant vi ingen bakenforliggende årsak.

Cerebral affeksjon av tuberkulose er også en meget alvorlig tilstand. Avhengig av nevrologiske funn klassifiseres denne til stadium 1 (ingen utfall), stadium 2 (utfall uten bevissthetstap) eller stadium 3 (koma) (8). Steroider er nå anbefalt ved alle disse stadiene for å forhindre eller begrense alvorlige komplikasjoner. Men på behandlingstidspunktet var det mer vage retningslinjer, og vi konsulterte fire infeksjonsmedisinere, som alle mente steroider ikke var indisert. Uansett stadium vil man også forlenge den ordinære medikamentelle behandlingen. Uten behandling dør pasienter med tuberkuløs meningitt vanligvis innen seks uker, med adekvat behandling synker mortaliteten til ca. $25 \%$ (9). Blant de overlevende vil omtrent halvparten ha ulike grader av varige nevrologiske skader. Vår pasient overlevde uten noen form for nevrologisk sekvele.

Etter oppstart av tuberkulostatikabehandling får en betydelig andel av pasientene en såkalt paradoks reaksjon - den eksisterende sykdommen forverres eller det kommer nye lesjoner på tross av adekvat behandling (10). En slik reaksjon er uforutsigbar både både når det gjelder debut, varighet og alvorlighetsgrad og er sannsynligvis immunologisk betinget. Vår pasient utviklet sannsynligvis dette, i og med at han fikk økende hodepine og epididymitt på motsatt side under pågående adekvat behandling. Ved en forverring av tilstanden må en slik reaksjon ikke forveksles med behandlingssvikt eller andre komplikasjoner til sykdommen.
Denne sykehistorien viser at helsepersonell må ha lav terskel for å mistenke tuberkulose hos utenlandskfødte som oppsøker legevakt eller akuttmottak av ulike grunner. Trange og dårlige boforhold for asylsøkere representerer en betydelig smitterisiko ved lungetuberkulose.

Pasienten har gitt samtykke til at artikkelen blir publisert.

Oppgitte interessekonflikter: Ingen

Litteratur

1. Doherty FJ. Ultrasound of the nonacute scrotum. Semin Ultrasound CT MR 1991; 12: 131-56.

2. Cek M, Lenk S, Naber KG et al. EAU guidelines for the management of genitourinary tuberculosis. Eur Urol 2005; 48: 353-62

3. Andreu J, Mauleón S, Pallisa E et al. Miliary lung disease revisited. Curr Probl Diagn Radiol 2002: 31: 189-97.

4. Gulsvik A. Tuberkulose. I: Foreningen for utgivelse av Norsk legemiddelhåndbok. Norsk legemiddelhåndbok for helsepersonell 2007. Oslo: Fagbokforlaget, 2007: 344-6.

5. Winje B, Mannsåker T, Heldal E et al. Tuberkulose i Norge i 2005. MSIS-rapport 2006; nr. 34: 33.

6. Dahle UR, Sandven P. Heldal E et al. Continued Low rates of transmission of Mycobacterium tuberculosis in Norway. J Clin Microbiol 2003; 41: 2968-73.

7. Türkvatan A, Kelahmet E, Yazgan C et al. Sonographic findings in tuberculous epididymo-orchitis. J Clin Ultrasound 2004: 32: 302-5.

8. Katti MK. Pathogenesis, diagnosis, treatment, and outcome aspects of cerebral tuberculosis. Med Sci Monit 2004; 10: RA215-29

9. Schlossberg D. Tuberculosis and nontuberculous mycobacterial infections. 5. utg. New York, NY: McGraw-Hill, 2006.

10. Breen RA, Smith CJ, Bettinson $\mathrm{H}$ et al. Paradoxical reactions during tuberculosis treatment in patients with and without HIV co-infection. Thorax 2004; 59: 704-7.

Manuskriptet ble mottatt 11.5. 2009 og godkjent 3.6. 2010. Medisinsk redaktør Anne Kveim Lie.

\title{
Noen sykdommer kommer tilbake
}

Effektive medisiner og omfattende forebyggende tiltak ga i 1960-70-årene håp om at tuberkulosen var under kontroll. Både globalt og i Norge sank forekomsten, og insidensen her i landet var blant de laveste i verden. Flere faktorer førte imidlertid til økende forekomst fra midten av 1980-årene. I flere land har kontrollprogrammene brutt sammen på grunn av krig, overbelastet helsevesen og mangelfull forståelse for nødvendigheten av ulike tiltak $(1,2)$. Økningen i insidens globalt skyldes $\mathrm{i}$ hovedsak økt reaktivering og smittespredning på grunn av hivepidemien. Her i landet er det i stor grad flere tuberkulo- setilfeller blant innvandrere som ligger bak. I tillegg har vi fătt økende utvikling av resistens, i hovedsak på grunn av mangelfull medikamentetterlevelse og kontroll.

Et av de viktigste milleniumsmålene for WHO var reduksjon i forekomst av og mortalitet ved tuberkulose (3). Det viktigste tiltaket - DOTS-strategien (direkte observert terapi) - har lenge vært anbefalt også her i landet og har vært søkt gjennomført ved hjelp av tuberkulosekoordinatorer. Det har vært reist tvil om nytten av DOTS-opplegget, som kan føre til stigmatisering og ofte er problematisk for mange pasienter. Det er imidlertid meget viktig at pasientene følges nøye opp, for også ved Oslo universitetssykehus, Ullevål, har vi sett utvikling av multiresistent tuberkulose (MDRTB) og sekundær spredning til en rekke pasienter som følge av mangelfull oppfølging, hovedsakelig $i$ et innvandrermiljø (upubliserte data). En vesentlig del av tilfellene av multiresistent tuberkulose i Norge skyldes mangelfull oppfølging og behandling.

Mens vekttap, nattesvette, høy senkningsreaksjon og anemi ofte skyldes malign sykdom, bør man hos innvandrere først og fremst tenke på tuberkulose. Sykdomsbildet 
hos innvandrere og ved hiv er ofte annerledes - sykdommen opptrer gjerne i form av ekstrapulmonal tuberkulose, som belyst $\mathrm{i}$ kasuistikken over.

Folkehelseinstituttet har nylig revidert tuberkuloseveilederen (2). Mens standardbehandlingen tidligere var en kombinasjon av tre medikamenter, anbefales nå oftere bruk av fire, inntil resultatet av resistensbestemmelsen foreligger. Ved mistanke om multiresistent tuberkulose bør det i tillegg også vurderes å gi et aminoglykosid (amikacin).

Bruk av kortikosteroider har vært kontroversielt. Ved oppstart av tuberkulosebehandling blir det frigjøring av antigener - med økt betennelsesreaksjon og såkalt paradoks reaksjon (forverring av symptomene). Ved tuberkuløs meningitt har det vært vanlig å anbefale steroider, selv om det har vært stilt spørsmål ved dokumentasjonen av effekt $(4,5)$, og noen fraråder dette. Etter nyere kontrollerte forsøk og i metaanalyser konkluderes det imidlertid med at steroider gir redusert mortalitet både ved meningitt og perikarditt $(1,2,5,6)$. Steroidbehandling gir også raskere symptombedring ved lungetuberkulose og demper en eventuell paradoks reaksjon. Undersøkelser tyder på at det ikke er fare for redusert antituberkuløs effekt av tuberkulosemedisinene (5). Ved samtidig hivinfeksjon med lave CD4-tall anbefales det å starte hivbehandlingen etter to ukers tuberkulosebehandling selv om man da kan få en sterkere paradoks reaksjon, men utsettelse av behandlingsstart har særlig i utviklingsland gitt $ø k t$ mortalitet og anbefales derfor ikke.

Rifampicin og isoniazid er hjørnesteiner i tuberkulosebehandlingen. Ved følsomhet for disse er seks måneders behandling nok ved pulmonal tuberkulose, og også i de fleste tilfeller av ekstrapulmonal tuberkulose. Ved tuberkulose i sentralnervesystemet og ved resistens må behandlingstiden forlenges til minimum 12-18 måneder (2).

\section{Johan N. Bruun}

j.n.bruun@medisin.uio.no

Infeksjonsmedisinsk avdeling

Universitetssykehuset Nord Norge 9038 Tromsø

og

Infeksjonsmedisinsk avdeling

Oslo universitetssykehus, Ullevål
Oppgitte interessekonflikter: Ingen

\section{Litteratur}

1. Mandell GJ, Douglas RG, Bennett JE, red. Principles and practice of infectious disease. 7. utg New York, NY: Churchill Livingstone, 2009.

2. Nasjonalt folkehelseinstitutt. Tuberkuloseveilederen Oslo: Nasjonalt folkehelseinstitutt, 2010. www.fhi.no (26.8.2010).

3. Steen TW, Drage M, Solum JA. How to combat HIV, tuberculosis and malaria? Tidsskr Nor Legeforen 2009; 129: 2504-8.

4. Laake H, Solem JH. Glukokortikosteroider og infeksjonssykdommer. Tidsskr Nor Lægeforen 1973; 93: 942-3.

5. Dooley DP, Carpenter JL, Rademacher S. Adjunctive corticosteroid therapy for tuberculosis: a critical reappraisal of the literature. Clin Infect Dis 1997: 25: 872-87.

6. Prasad K, Singh MB. Corticosteroids for managing tuberculous meningitis. The Cochrane Collaboration 2009. Cochrane Database Syst Rev 2009; nr. 1.

Manuskriptet ble mottatt 26.8. 2010 og godkjent 2.9. 2010. Medisinsk redaktør Anne Kveim Lie. 